\title{
EFFECT OF SOIL NUTRIENT MANAGEMENT AND COOKING METHODS ON NUTRIENT AND PHYTOCHEMICAL COMPOSITION OF IPOMEABATATAS (UMUSPO 3 VARIETY)
}

\author{
Ojimelukwe P.C. ${ }^{\bowtie}$, Okpanku U.U ${ }^{1}$ and Ugwuona F. U. ${ }^{1}$ \\ ${ }^{I}$ Department of Food Science and Technology, College of Applied Food Sciences and Tourism, Michael Okpara \\ University of Agriculture, Umudike, Nigeria \\ philippaco60@gmail.com \\ https://doi.org/10.34302/crpjfst/2020.12.5.9 \\ Article history: \\ Received: \\ 28 August 2020 \\ Accepted: \\ 25 December 2020 \\ Keywords: \\ Soil nutrient, \\ Management, \\ Cooking methods, \\ UMUSPO 3 potato, \\ Nutrient composition, \\ Phytochemicals, \\ Carotenoid retention.

\section{ABSTRACT} \\ Findings from the investigations on the effects of different soil nutrient \\ managements and cooking methods on nutrient and phytochemical \\ composition of orange-fleshed sweet potato (Umudike Sweet Potato Variety \\ 3) (UMUSPO 3 Ipomea batatas) are reported in this article. UMUSPO 3 \\ potato vines (main plot) were planted on eight sub- plots treated with \\ different soil nutrients (Poultry manure, agrolyser and NPK) combinations \\ (VB1 - VB8) and a control (VB9) at the National Root Crops Research \\ Institute experimental farm, Umudike, Abia State, Nigeria. Potato tubers \\ were harvested after 4 months of planting and both cooked and raw samples \\ were subjected to chemical and sensory analysis. Carbohydrate and dry \\ matter contents were highest and respectively $16.4 \%$ and $29.79 \%$ in potatoes \\ harvested from the control soil (VB9). Both control and treated soils yielded \\ potatoes that were high in calcium $(86.94-96.47 \mathrm{mg} / 100 \mathrm{~g})$, magnesium \\ (73.62 - $86.87 \mathrm{mg} / 100 \mathrm{~g})$, phosphorus (151.26 - $195.97 \mathrm{mg} / 100 \mathrm{~g})$, potassium \\ $(790.30-901.54 \mathrm{mg} / 100 \mathrm{~g})$ and sodium $(74.50-81.84 \mathrm{mg} / 100 \mathrm{~g})$. Only soil \\ treatments with NPK 15:15:15 at $400 \mathrm{~kg} / \mathrm{ha}$ (VB5) improved protein \\ contents of raw potatoes from $5.26 \%$ to $6.13 \%$ while other soil treatments \\ decreased the protein content. Potato harvested from the control and various \\ soil treatments (VB1 -VB8) were rich in vitamin C (53.34 - $95.37 \mathrm{mg} / 100$ \\ g) and carotene $(28.52-29.73 \mathrm{mg} / 100 \mathrm{~g})$ but relatively low in the B \\ vitamins. Soil treatments VB1 to VB8 did not improve vitamin contents of \\ potatoes beyond that of the control for vitamin B1. Cooking methods and \\ cooking time affected carotenoid retention in UMUSPO 3 potato. \\ Carotenoid retention was higher in oven-dried samples than in roasted and \\ boiled samples. Oven-drying for $24 \mathrm{~h}$ decreased total carotenoid retention to \\ $76.4 \%$, and for $48 \mathrm{~h}$ to $36.3 \%$. Boiling for $10 \mathrm{~min}$ decreased carotenoid \\ content to $56.4 \%$, and for $30 \mathrm{~min}$ to $17.1 \%$. Roasting for $10 \mathrm{~min}$ reduced it \\ to $50.6 \%$, and for $30 \mathrm{~min}$ to $30.9 \%$.
}

\section{INTRODUCTION}

Sweet potatoes

(Ipomeabatata(L.) LAM.), arefamine crops cultivated throughout the tropics and warm temperate regions of the world for their starchy roots (Mitra 2012). Potatoes are good sources of carbohydrates, lipids, proteins, vitamins, and minerals. The intensity of the orange-fleshed colour is directly correlated to the beta-carotene content of orange-fleshed sweet potato (OFSP).

Sweet potato is grown to a lesser extent in West Africa where it is priced by the region's poor farmers. In West Africa, it is valued as a reliable, low input, food security crop, for its commercial potential. Sweet potato requires moderate temperature $\left(21-26^{\mathrm{O}} \mathrm{C}\right)$ and a well distributed rainfall of $75-150 \mathrm{~cm}$. The crop 
requires a lot of sunshine, tolerates drought to some extent but cannot withstand water logging (Nedunchezhiyanet al., 2007). Sandy loam with clay subsoil is the ideal. Heavier, clayey soils restrict development of the storage roots as a result of compacted lumps of soil (Nedunchezhiyanet al., 2012). Sandy soil encourages the development of long cylindrical pencil-like roots (Nedunchezhiyanet al., 2007). Thus, soil types, rainfall distribution and soil management practices influence yield and composition of sweet potatoes. Also, processing and cooking methods influence final composition and sensory properties of foods including sweet potatoes (Yang and Gradi, 2008; Chukwuet al, 2010). Potato can be boiled, fried or grilled, steamed, braised, baked and roasted (Abidin, 2004). Two most common ways of consuming potato in Nigeria are boiling in water and frying in refined vegetable oil or palm oil.This study investigated the effect of different soil nutrient management and cooking methods on the nutrient composition, phytochemical content and retention of carotenoids in an orange-fleshed sweet potato (UMUSPO 3 Ipomeabatatas).Results for detailed carotenoid profile and constituents of other OFSP varieties have been reported in literature (Ojimelukwe and Okpanku, 2020). Figure 1 shows the UMUSPO3 Orange-fleshed sweet potato variety.

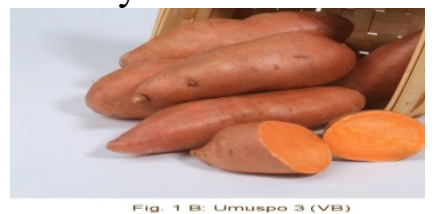

Figure 1. UMUSPO3 Orange-fleshed sweet potato variety

\section{MATERIALS AND METHODS}

\subsection{Raw Materials}

The raw materials were poultry manure obtained from the poultry farm of Michael Okpara University of Agriculture, Umudike, Nigeria, artificial nitrogen fertilizer (NPK) obtained from the Abia State Agricultural Development Programme, and orange fleshed sweet potato (Umudike sweet potato variety 3 (UMUSPO 3Ipomeabatatasvariety) vine cuttings obtained from a students' research farm at the National Root Crops Research Institute, Umudike, Abia State, Nigeria.

\subsection{Field Work Experimental Design and Treatments}

The UMUSPO 3 sweet potato variety was planted at the National Root Crops Research Institute experimental farm, Umudike, Abia State, Nigeria situated between latitude $05^{\circ} 29 \mathrm{~N}$; longitude $07^{\circ} 33 \mathrm{E}$ and an altitude of $122 \mathrm{~m}$. The sandy loam soil used for planting contained $78.8 \%$ sand, $6.8 \%$ silt, $14.4 \%$ clay, $\mathrm{pH} 4.7$, $1.59 \%$ organic matter, $0.08 \%$ Nitrogen $(\mathrm{N}), 32.1$ $\mathrm{mg} / \mathrm{kg}$ Phosphorus (P) and $0.35 \mathrm{mg} / \mathrm{kg}$, Potassium (K). (Ukom et al., 2011). The treatment wasasplit plot in randomized complete block design with three replications. Main plot was UMUSPO 3 Orange-Fleshed Sweet Potato (OFSP) while sub-plots were eight nutrient combinations and a control, viz: VB1 = poultry manure at $5.0 \times 10^{3} \mathrm{~kg} / \mathrm{ha} ; \mathrm{VB} 2=$ Poultry manure at $2.5 \times 10^{3} \mathrm{~kg} / \mathrm{ha}+\mathrm{NPK} 15: 15: 15$ at 200 $\mathrm{kg} / \mathrm{ha}$; VB3 = Agrolyser $2.7 \mathrm{~kg} / \mathrm{ha}+\mathrm{NPK}$ at 200 $\mathrm{kg} / \mathrm{ha} ; \mathrm{VB} 4=$ Poultry manure at $5.0 \times 10^{3} \mathrm{~kg} / \mathrm{ha}$ $+\mathrm{NPK}$ at $200 \mathrm{~kg} / \mathrm{ha} ; \mathrm{VB} 5=\mathrm{NPK}$ 15:15:15 at $400 \mathrm{~kg} / \mathrm{ha} \mathrm{VB6}=$ Agrolyzer at $5.3 \mathrm{~kg} / \mathrm{ha} ; \mathrm{VB} 7=$ Poultry manure at $10.0 \times 10^{3} \mathrm{~kg} / \mathrm{ha}$; VB8 = Poultry manure at $2.5 \times 10^{3} \mathrm{~kg} / \mathrm{ha}+\mathrm{NPK}$ at 200 $\mathrm{kg} / \mathrm{ha}+$ Agrolyser at $2.7 \mathrm{~kg} / \mathrm{ha}$; VB9 $=$ Control (untreated soil).

(Agrolyser contains: $\mathrm{Ca}-20.4 \% ; \mathrm{Na}-$ $1.04 \% ; \mathrm{Zn}-0.11 \%, \mathrm{~S}-2.72 \%$; Fe, Mn, Mo trace).The poultry manure had $\mathrm{pH} 7.06, \mathrm{~N}$ $2.17 \%$, P $1.06 \%$ and $\mathrm{K} 0.62 \%$, and was applied into appropriate plots after ridging while NPK were applied by band placement 4 weeks after planting. Each of the sub-plots measured $3 \mathrm{~m} \mathrm{x}$ $2 \mathrm{~m}\left(6 \mathrm{~m}^{2}\right)$. Sweet potato vine cuttings of $20 \mathrm{~cm}$ length with at least 4 nodes were planted along the crest of the ridges. Replacement of vacant stands was done at 2 weeks after planting. Potato roots were harvested after 4 months of planting. The raw samples were subjected to chemical analysis while the processed (boiled, oven-dried and roasted) samples were subjected to carotenoid analysis only. 


\subsection{Methods}

\subsubsection{Determination of Proximate composition of UMUSPO 3 sweet potato roots}

Moisture, crude protein $(\% \mathrm{~N} \times 6.25)$, fat, fibre and ash contents of the potato samples were determined in triplicates using standard procedures of the Association of Official Analytical Chemist (AOAC, 2000).

\subsubsection{Mineral Content Determination}

Mineral contents were determined using the method of AOAC (2000). Milled dry potato samples $(2.0 \mathrm{~g})$ of $0.5 \mathrm{~mm}$ size using a milling machine (Superintermentmilling machine, Model No: 242, Japan) was mixed with $5 \mathrm{ml}$ of a digestion mixture (selenium $+\mathrm{H}_{2} \mathrm{SO}_{4}+$ salicylic acid solution) in $150-\mathrm{ml}$ conical flask, allowed to stand overnight $(12 \mathrm{~h})$ and then digested at $30^{\circ} \mathrm{C}$ for $2 \mathrm{~h}$. Concentrated $\mathrm{H}_{2} \mathrm{SO}_{4}$ $(5 \mathrm{ml})$ was added, and the mixture heated more vigorously at higher temperature until completely digested, releasing profuse fumes. The digest was cooled, transferred into a $50 \mathrm{ml}$ volumetric flask and made up to the mark with distilled water. This was used for the determinations. Calcium ( $\mathrm{Ca}$ ) and magnesium $(\mathrm{Mg})$ contents were determined by the EDTA versanatecomplexometric titration method; potassium $(\mathrm{K})$ and sodium $(\mathrm{Na})$ contents by the flame photometric method while phosphorus (P) was determined by the Vanado-molybdate reagent method using spectrophotometer.

\subsubsection{Vitamin Determination}

\subsubsection{Determination of pro-vitamin $A$}

Pro-vitamin A ( $\beta$-carotene) content was determined using method of the Association of Vitamin Chemist as described by Kirk and Sawyer (1998). Milled dried potato (5 g) was mixed with $30 \mathrm{ml}$ of absolute ethanol and $3 \mathrm{ml}$ of $50 \% \mathrm{KOH}$ solution; boiled under reflux for 30 minutes, cooled rapidly, and $30 \mathrm{ml}$ of distilled water added. The mixture was carefully washed thrice, each with $50 \mathrm{ml}$ of ether into a separating funnel after which the upper aqueous layer was discarded. The lower oily layer was again washed thrice, each with $50 \mathrm{ml}$ distilled water but with caution to avoid formation of emulsion. The washed extract (Vitamin A) was evaporated to near dryness over a steam bath and then allowed to dry completely at room temperature $\left(25^{\circ} \mathrm{C}-27^{\circ} \mathrm{C}\right)$ in a stream of air. It was dissolved in $10 \mathrm{ml}$ of isopropyl alcohol and its absorbance read in a spectrophotometer (72 series VIS/UV, England) at $325 \mathrm{~nm}$ with a reagent blank set at zero. Also, a standard vitamin A (retinol) was dissolved in isopropyl alcohol and its absorbance read at the same wavelength as the sample. Vitamin A content was calculated as follows:

$$
\text { Vitamin A }\left(\frac{\mathbf{m g}}{\mathbf{1 0 0}} \mathbf{g}\right)=\frac{(100 \times A u \times C)}{W \times A s},
$$

Where $\mathrm{W}=$ Weight of sample, $\mathrm{Au}=$ Absorbance of sample, As = Absorbance of standard, $\mathrm{C}=$ Concentration.

2.3.3.2.Determination of vitamin $C$ (ascorbic Acid)

Ascorbic acid contentwas determined using Basket titration method described by Okwu and $\mathrm{Ndu}$ (2006). A ground quantity (5 g) of the sample was thoroughly mixed with $50 \mathrm{ml}$ of distilled water, allowed to stand for $30 \mathrm{~min}$ at room temperature $\left(25^{\circ} \mathrm{C}-27^{\circ} \mathrm{C}\right)$, shaken and then filtered through What man No. 42 filter paper. The filtrate (extract) was treated with 20 $\mathrm{ml}$ of $10 \%$ potassium iodide solution followed by titration with Copper sulphate $\left(\mathrm{CuSO}_{4}\right)$ solution. Vitamin $\mathrm{C}$ content was calculated as follow: Vitamin $C(\mathrm{mg} / 100)=$

$$
\operatorname{Vitamin} C(\mathrm{mg} \text { per } 100 \mathrm{~g})=\frac{100}{W} \times 0.88 \mathrm{mg} \times \text { Titre , }
$$

Where $\mathrm{W}=$ Weight of sample analyzed and $1 \mathrm{ml}$ of $0.01 \mathrm{~m} \mathrm{CuSO}_{4}$ solution $=0.88 \mathrm{mg}$ vitamin C.

\subsubsection{Determination of vitamin $B_{1}$ (Thiamine)}

Thiamine was determined according to method of Jorg Augustin as slightly modified by Okwu and Ndu, (2006). Five (5) g of sample was homogenized in normal ethanolic Sodium hydroxide solution, filtered through What man No. 42 filter paper, and an aliquot $(10 \mathrm{ml})$ of the filtrate mixed with $10 \mathrm{ml}$ of $0.1 \mathrm{~N}$ potassium dichromate solution. Also, $10 \mathrm{ml}$ of standard thiamine solution was treated with $10 \mathrm{ml}$ of $0.1 \mathrm{~N}$ Potassium dichromate solution as well as with a 
reagent blank. The absorbance was read spectrophotometrically at $36 \mathrm{~nm}$ (72 series VIS/UV, England), and thiamine content calculated thus:

Thiamine $\mathrm{mg} / 100 \mathrm{~g}=\frac{100}{W} \times \frac{A u}{A s} \times C \times \frac{V f}{V a}$,

Where: $\mathrm{W}=$ Weight of sample analyzed, $\mathrm{Au}$ $=$ Absorbance of sample, As $=$ Absorbance of standard, $\mathrm{C}=$ Concentration $1 \mu / \mathrm{ml}$.

2.3.3.4.Determination of vitamin $B_{2}$ (riboflavin)

Riboflavin was determined calorimetrically using the method of Jorg Augustin as described by Okwu and Ndu (2006). Five grams (5 g) of ground dry Potato sample (5) was extracted with $50 \mathrm{ml}$ of $50 \%$ ethanol with intermittent shaking for 1 hour. This was filtered through what man No. 42 filter paper, and $10 \mathrm{ml}$ of the filtrate mixed with $10 \mathrm{ml}$ each of $5 \% \mathrm{KMnO}_{4}$ solution and $30 \%$ Hydrogen peroxide solution. The mixture was maintained on a hot water bath for 30 minutes, and thereafter, $20 \mathrm{ml}$ of $40 \%$ Sodium sulphate solution was added, and the mixture made up to $50 \mathrm{ml}$ with distilled water. The absorbance was measured spectrophotometrically at $520 \mathrm{~nm}$. A standard riboflavin solution was prepared similarly, the absorbance measured similarly, and vitamin $\mathrm{B}_{2}$ content calculated thus:

Riboflavin $\mathrm{mg} / 100 \mathrm{~g}=\frac{100}{W} \mathrm{x} \mathrm{Au} / \mathrm{As} \times \mathrm{C} \times$ Vf/Va,

Where $\mathrm{w}=$ weight of sample analyzed, $\mathrm{Au}=$ Absorbance of sample, As $=$ Absorbance of standard, $\mathrm{C}=$ Concentration of standard $(\mathrm{mg} / 1 \mathrm{ml}), \mathrm{Vf}=$ Total volume of extract, and $\mathrm{Va}$ $=$ Volume of extract analyzed.

\subsubsection{Determination of vitamin $B_{3}$ (niacin)}

Niacin content was determined by the Skater colorimetric method as described by Okwu (2004). Five grams (5 g) of ground dried potato was mixed with $30 \mathrm{ml}$ of normal $\mathrm{H}_{2} \mathrm{SO}_{4}$ solution, shaken for 30 minutes and filtered through Whatman No. 42 filter paper. The extract was made alkaline by adding 3 drops of conc. $\mathrm{NH}_{4} \mathrm{OH}$, and $10 \mathrm{ml}$ of extract treated with $5 \mathrm{ml}$ of normal Potassium ferrocynanide solution, followed by $5 \mathrm{ml}$ of $0.02 \mathrm{NH}_{2} \mathrm{SO}_{4}$ solution. This was allowed to stand for $5 \mathrm{~min}$ at room temperature $\left(25^{\circ} \mathrm{C}-27^{\circ} \mathrm{C}\right)$ after which absorbance was read at $470 \mathrm{~nm}$. Niacin content was calculated thus:

Niacin $(\mathrm{mg} / 100 \mathrm{~g})=\frac{100}{W} \times \mathrm{Au} / \mathrm{As} \times \mathrm{C} \times \mathrm{Vf} / \mathrm{Va}$,

Where: $\mathrm{W}=$ Weight of sample analyzed, $\mathrm{Au}$ $=$ Absorbance of sample, As = Absorbance of standard, $\mathrm{C}=$ Concentration $1 \mu / \mathrm{ml}, \mathrm{Vf}=$ Total volume of extract, and $\mathrm{Va}=$ Volume of extract analysed.

\subsection{Determination of Phytochemical Constituents}

\subsubsection{Determination of tannin content}

The vanillin-HClmethod described by Niseteo et al.(2012) was used. Ground dry potato sample $(1 \mathrm{~g})$ was mixed vigorously with $3 \mathrm{ml}$ of methanol at room temperature $\left(28 \pm 2^{\circ} \mathrm{C}\right)$ and rested for $1 \mathrm{~min}$ to extract tannin. This was filtered, and $3 \mathrm{ml}$ of the extract reacted with $3 \mathrm{ml}$ each of $0.1 \mathrm{~mol} \mathrm{NH}_{4} \mathrm{Cl}$ and $0.08 \mathrm{~mol} \mathrm{k}_{3} \mathrm{Fe}$ $(\mathrm{CN})_{6}$ for $2 \mathrm{~min}$ in a test tube. Absorbance was read at $720 \mathrm{~nm}$, and tannin content extrapolated from a standard curve previously prepared with catechin as tannin standard. The process was repeated in triplicates and the average value expressed in $\mathrm{mg} / 100 \mathrm{~g}$ tannin content

\subsubsection{Alkaloid Determination}

Five grams of the sample were weighed into a $250 \mathrm{ml}$ beaker and $200 \mathrm{ml}$ of $20 \%$ acetic acid in ethanol was added and covered to stand for 4 hours. This was filtered and the extract was concentrated using a water-bath to one quarter of the original volume. Concentrated Ammonium hydroxide was added drop-wise to the extract until precipitation was complete. The whole solution was allowed to settle and the precipitate was collected by filtration, dried and weighed (Harborne, 1973).

\subsubsection{Determination of total flavonoid Content}

The Iron (iii) Chloride $\left(\mathrm{AlCl}_{3}\right)$ method of AOAC(2000) was adopted.Ten gram of potato 
powder (10 g) was extracted repeatedly with 100 $\mathrm{ml}$ of $80 \%$ aqueous methanol at room temperature and filtered through what man filter paper No $42(125 \mathrm{~mm})$. Aliquot $(1.5 \mathrm{ml})$ of filtrate was mixed with $1.5 \mathrm{ml}$ of a $2 \%$ $\mathrm{AlCl}_{3} .6 \mathrm{H}_{2} \mathrm{O}(2 \mathrm{~g}$ in $100 \mathrm{ml}$ methanol) solution, shaken and incubated for $10 \mathrm{~min}$ at room temperature. Absorbance was read at $367 \mathrm{~nm}$ after incubating for $10 \mathrm{~min}$ at room temperature in the dark. A standard curve for flavonoid was prepared from 0.0, 0.02, 0.05, 0.10, 0.50, 1.50 and $2.0 \mathrm{mg} / \mathrm{ml}$ garlic acid concentrations at 367 $\mathrm{nm}$ and flavonoid content (expressed as garlic acid equivalents (GAE/100g) extrapolated from the curve.

\subsubsection{Determination of oxalate content:}

Oxalate content was determined as described by Oke (1966). One gram of potato powder (W1) was mixed with $190 \mathrm{ml}$ of deionized water and $10 \mathrm{ml}$ of $6 \mathrm{M} \mathrm{HCl}$; and then digested at $90^{\circ} \mathrm{C}$ for $4 \mathrm{~h}$. This was centrifuged at $2000 \mathrm{rpm}$ for $5 \mathrm{~min}$; the supernatant diluted with distilled water to $250 \mathrm{ml}$ and titrated with concentrated Ammonium hydroxide solution to faint yellow colour end point, using methyl orange indicator.The resultant mixture was heated $\left(90{ }^{\circ} \mathrm{C}\right)$ for $20 \mathrm{~min}$ and $10 \mathrm{ml}$ of $5 \%$ Calcium chloride $\left(\mathrm{CaCl}_{2}\right)$ solution added to precipitate Calcium oxalate. This was rested overnight, centrifuged, decanted and the residue oven-dried at $60^{\circ} \mathrm{C}$ for $48 \mathrm{~h}$. This was cooled and weighed (W2). This was repeated three times and the mean weight expressed as:

$\%$ Oxalate content $=\frac{W 2}{W 1} \times \frac{100}{1}$

\subsection{Data Analysis}

Data obtained were subjected to descriptive test and one-way analysis of variance used to determine level of significance, using the SPSS software version 17. Means where significantly different at $\mathrm{p}<0.05$ were separated using Duncan Multiple Range Test (DMRT).

\section{RESULTS AND DISCUSSION}

3.1.Proximate Composition of Orange Fleshed Potato (UMUSPO 3 Ipomea Batatas Variety) Grown under Different Soil Nutrient Management treatments

Table 1 shows the proximate composition of Ipomea batatas(variety: UMUSPO 3) cultivated on soils with different nutrient treatments. The moisture content ranged from $70.21 \mathrm{~g} / 100 \mathrm{~g}$ in potatoes planted onVB9 (untreated plot) andon VB8(treated with poultry manure at $2.5 \times 10^{3}$ $\mathrm{kg} /$ ha plus NPK at $200 \mathrm{~kg} / \mathrm{ha}$ plus Agrolyser at $2.7 \mathrm{~kg} / \mathrm{ha}$ )to $76.08 \mathrm{~g} / 100 \mathrm{~g}$ in potatoes planted on VB2(treated with poultry manure at $2.5 \times 10^{3}$ $\mathrm{kg} / \mathrm{ha}$ plus NPK at $200 \mathrm{~kg} / \mathrm{ha}$ ).Moisture content increased with soil nutrient treatments, implying that the crops will be more prone to post-harvest biochemical activities and may have shorter shelf life on storage.

It was only soil nutrient treatment VB5(NPK $15: 15: 15$ at $400 \mathrm{~kg} / \mathrm{ha}$ ) that improved protein content from $5.26 \%$ to $6.13 \%$ in OFSP potatoes. Treatments VB3 and VB6 did not significantly ( $p>0.05)$ affect protein content of potatoes. Other treatments decreased this nutrient from $5.26 \%$ to $4.37 \%$ through $3.39 \%$ protein contents. The $3.49 \mathrm{~g} / 100 \mathrm{~g}-6.13 \mathrm{~g} / 100 \mathrm{~g}$ protein contents in this work was comparable with the values reported by Ukom et al (2009), but higher than the $1.2 \%$ to $2.3 \%$ reported by Onuhet al. (2004) on harvested potatoes. Carbohydrate content increased from $16.40 \%$ in the control to $19.04 \%$ in VB8 (potatoes grown on Poultry manure at $2.5 \times 10^{3} \mathrm{~kg} / \mathrm{ha}+\mathrm{NPK}$ at $200 \mathrm{~kg} / \mathrm{ha}+$ Agrolyser at $2.7 \mathrm{~kg} / \mathrm{ha})$. Also, dry matter content (29.79\%) was also decreased by all the soil nutrient treatments, except in treatment VB8where it was not $(p>0.05)$ significantly affected. Crude fibre contents of the control (VB9) and VB3, were not significantly different $(p>0.05)$ from one another. Soil nutrient treatments VB4 to VB6; VB7 and VB8 decreased crude fibre content of potatoes which ranged from $3.03 \%$ to $5.05 \%$ (but the values were not significantly different $(p>0.05)$. The dry matter content was relatively lower for other treatments, except for VB6,(1.71\%). Crude fat decreased from 1.68\% in potatoes fromVB9, (the control), to as low as $1.51 \%$ in potatoes from treated soils. Soil 
nutrient management treatments decreased the fat content of sweet potatoes (in comparison with the control) except for those grown on Agrolyzer at $5.3 \mathrm{~kg} / \mathrm{ha}(\mathrm{VB} 6)$.

Table 1. Effect of different soil nutrient management on the proximate composition $(\mathrm{g} / 100 \mathrm{~g})$ of UMUSPO 3 Ipomeabatatas Variety

\begin{tabular}{|l|c|c|c|c|c|c|c|}
\hline $\begin{array}{l}\text { Treat } \\
\text { ments }\end{array}$ & Moisture & Ash & Crude Fat & $\begin{array}{c}\text { Crude } \\
\text { Fibre }\end{array}$ & Protein & $\begin{array}{c}\text { Carbohydrat } \\
\text { e }\end{array}$ & Dry Matter \\
\hline VB1 & $73.10^{\mathrm{d}} \pm 0.14$ & $2.07^{\mathrm{a}} \pm 0.04$ & $1.56^{\mathrm{d}} \pm 0.01$ & $3.09^{\mathrm{c}} \pm 0.01$ & $4.37^{\mathrm{c}} \pm 0.01$ & $15.82^{\mathrm{c}} \pm 0.23$ & $26.90^{\mathrm{d}} \pm 0.14$ \\
\hline VB2 & $76.08^{\mathrm{a}} \pm 0.03$ & $1.2 \pm 0.02$ & $1.64^{\mathrm{c}} \pm 0.00$ & $3.06^{\mathrm{c}} \pm 0.02$ & $4.37^{\mathrm{c}} \pm 0.01$ & $13.65^{\mathrm{g}} \pm 0.02$ & $23.92^{\mathrm{b}} \pm 0.03$ \\
\hline VB3 & $72.09^{\mathrm{e}} \pm 0.01$ & $0.99^{\mathrm{e}} \pm 0.00$ & $1.66^{\mathrm{bc}} \pm 0.01$ & $5.09^{\mathrm{a}} \pm 0.02$ & $5.25^{\mathrm{b}} \pm 0.01$ & $14.93^{\mathrm{e}} \pm 0.03$ & $27.91^{\mathrm{c}} \pm 0.01$ \\
\hline VB4 & $74.78^{\mathrm{b}} \pm 0.03$ & $0.99^{\mathrm{e}} \pm 0.01$ & $1.52^{\mathrm{e}} \pm 0.00$ & $4.06^{\mathrm{b}} \pm 0.02$ & $3.49^{\mathrm{d}} \pm 0.02$ & $15.18^{\mathrm{d}} \pm 0.05$ & $25.22^{\mathrm{g}} \pm 0.03$ \\
\hline VB5 & $71.09^{\mathrm{f}} \pm 0.02$ & $1.66^{\mathrm{b}} \pm 0.00$ & $1.55^{\mathrm{d}} \pm 0.01$ & $3.03^{\mathrm{c}} \pm 0.01$ & $6.13^{\mathrm{a}} \pm 0.01$ & $16.55^{\mathrm{b}} \pm 0.01$ & $28.92^{\mathrm{b}} \pm 0.02$ \\
\hline VB6 & $73.08^{\mathrm{d}} \pm 0.01$ & $0.81^{\mathrm{f}} \pm 0.01$ & $1.71^{\mathrm{a}} \pm 0.00$ & $4.05^{\mathrm{b}} \pm 0.07$ & $5.26^{\mathrm{b}} \pm 0.00$ & $14.37^{\mathrm{f}} \pm 0.06$ & $26.19^{\mathrm{e}} \pm 0.01$ \\
\hline VB7 & $74.41^{\mathrm{c}} \pm 0.01$ & $0.80^{\mathrm{f}} \pm 0.00$ & $1.55^{\mathrm{d}} \pm 0.01$ & $3.98^{\mathrm{b}} \pm 0.00$ & $4.38^{\mathrm{c}} \pm 0.00$ & $14.89^{\mathrm{e}} \pm 0.00$ & $25.59^{\mathrm{f}} \pm 0.01$ \\
\hline VB8 & $70.21^{\mathrm{g}} \pm 0.01$ & $0.81^{\mathrm{f}} \pm 0.01$ & $1.51^{\mathrm{e}} \pm 0.01$ & $4.07^{\mathrm{b}} \pm 0.04$ & $4.37^{\mathrm{c}} \pm 0.00$ & $19.04^{\mathrm{a}} \pm 0.06$ & $29.79^{\mathrm{a}} \pm 0.01$ \\
\hline VB9 & $70.21^{\mathrm{g}} \pm 0.01$ & $1.41^{\mathrm{c}} \pm 0.01$ & $1.68^{\mathrm{ab}} \pm 0.01$ & $5.05^{\mathrm{a}} \pm 0.04$ & $5.26^{\mathrm{b}} \pm 0.01$ & $16.40^{\mathrm{b}} \pm 0.04$ & $29.79^{\mathrm{a}} \pm 0.01$ \\
\hline
\end{tabular}

Values are means \pm SD. means with different superscripts in the same column are significantly different $(\mathrm{p}<0.05), \mathrm{VB} 1=$ poultry manure at $5.0 \times 10^{3} \mathrm{~kg} / \mathrm{ha} ; \mathrm{VB} 2=$ Poultry manure at $2.5 \times 10^{3} \mathrm{~kg} / \mathrm{ha}+\mathrm{NPK}$ $15: 15: 15$ at $200 \mathrm{~kg} / \mathrm{ha} ; \mathrm{VB} 3=$ Agrolyser $2.7 \mathrm{~kg} / \mathrm{ha}+\mathrm{NPK}$ at $200 \mathrm{~kg} / \mathrm{ha} ; \mathrm{VB} 4=$ Poultry manure at $5.0 \mathrm{x}$ $10^{3} \mathrm{~kg} / \mathrm{ha}+\mathrm{NPK}$ at $200 \mathrm{~kg} / \mathrm{ha}$; VB5 $=$ NPK 15:15:15 at $400 \mathrm{~kg} / \mathrm{ha} ; \mathrm{VB} 6=$ Agrolyzer at $5.3 \mathrm{~kg} / \mathrm{ha} ; \mathrm{VB} 7=$ Poultry manure at $10.0 \times 10^{3} \mathrm{~kg} / \mathrm{ha} ; \mathrm{VB} 8=$ Poultry manure at $2.5 \times 10^{3} \mathrm{~kg} / \mathrm{ha}+\mathrm{NPK}$ at $200 \mathrm{~kg} / \mathrm{ha}+$ Agrolyser at $2.7 \mathrm{~kg} / \mathrm{ha}$; VB9 $=$ Control

\subsection{Effect of Different Soil Nutrient Management Treatments on Mineral Content of UMUSPO IpomeaBatatasVariety (FW) (Mg/100 G)}

Table 2 shows mineral composition potatoes samples (UMUSPO 3Ipomeabatatas) cultivated on soils given different nutrient managements. All the potato samples, including those harvested from the control, untreated soil (VB9) were rich in calcium $(86.94-96.47 \mathrm{mg} / 100 \mathrm{~g})$, magnesium (73.62 - $86.87 \mathrm{mg} / 100 \mathrm{~g})$, phosphorus (151.26 - $195.97 \mathrm{mg} / 100 \mathrm{~g})$, potassium $(790.30-901.54 \mathrm{mg} / 100 \mathrm{~g})$ and sodium $(74.50-81.84 \mathrm{mg} / 100 \mathrm{~g})$. Soil nutrient treatments significantly $(\mathrm{p}<0.05)$ improved phosphorus contents of potatoes; this ranged from $151.26 \mathrm{mg} / 100 \mathrm{~g}$ in the control potatoes to $152.87 \mathrm{mg} / 100 \mathrm{~g}$ through $159.97 \mathrm{mg} / 100 \mathrm{~g}$ in potatoes from the treated soils. Magnesium and sodium contents $(\mathrm{mg} / 100 \mathrm{~g})$ significantly $(\mathrm{p}<$ 0.05 ) decreased with soil nutrient management.
Treatment VB7 produced potatoes with more balanced minerals for human health. The approximate 11: 1 ratio of potassium to sodium in this UMUSPO 3Ipomeabatatas, is geometrically higher than the minimum 2: 1 recommended for hypertensive-free diets supports its use by hypertensive patients.

Calcium contributes in normal bone and teeth development, blood clotting and enzymic function (Gropper et al., 2005; Ojimelukweet al., 2005). Magnesium is needed for heart and muscles functioning, maintenance of blood pressure and myocardial contraction (Umesh, 2009). Phosphorus helps bone and teeth development, sugar phosphate is involved in carbohydrate and fat metabolism; and helps in cell activity and maintenance of $\mathrm{pH}$ in the body (Gropper et al., 2005; Ojimelukweet al., 2005). VB3 gave the best improvement of the mineral content amongst all the treatments. 
Table 2. Effect of different soil nutrient management treatments on mineral content of UMUSPO 3Ipomeabatatasvariety $(\mathrm{mg} / 100 \mathrm{~g})$

\begin{tabular}{|l|l|l|l|l|l|}
\hline Treatment & Calcium & Magnesium & Phosphorus & Potassium & Sodium \\
\hline VB1 & $94.95^{\mathrm{ab}} \pm 0.03$ & $73.62^{\mathrm{b}} \pm 1.90$ & $152.87^{\mathrm{e}} \pm 2.28$ & $901.54^{\mathrm{a}} \pm 1.54$ & $74.50^{\mathrm{d}} \pm 1.04$ \\
\hline VB2 & $93.46^{\mathrm{bc}} \pm 0.30$ & $75.43^{\mathrm{b}} \pm 0.27$ & $159.05^{\mathrm{a}} \pm 0.62$ & $863.61^{\mathrm{b}} \pm 1.49$ & $80.93^{\mathrm{ab}} \pm 0.00$ \\
\hline VB3 & $96.47^{\mathrm{a}} \pm 1.12$ & $75.03^{\mathrm{b}} \pm 0.10$ & $156.63^{\mathrm{bcd}} \pm 1.00$ & $797.34^{\mathrm{c}} \pm 1.57$ & $77.81^{\mathrm{bd}} \pm 2.34$ \\
\hline VB4 & $95.43^{\mathrm{ab}} \pm 1.82$ & $76.52^{\mathrm{b}} \pm 0.28$ & $159.57^{\mathrm{a}} \pm 0.23$ & $867.06^{\mathrm{b}} \pm 1.90$ & $81.98^{\mathrm{a}} \pm 2.66$ \\
\hline VB5 & $93.10^{\mathrm{c}} \pm 0.85$ & $73.49^{\mathrm{b}} \pm 0.34$ & $155.22^{\mathrm{cd}} \pm 1.29$ & $785.72^{\mathrm{d}} \pm 0.62$ & $77.28^{\mathrm{cd}} \pm 1.16$ \\
\hline VB6 & $94.85^{\mathrm{abc}} \pm 0.47$ & $74.73^{\mathrm{b}} \pm 0.89$ & $157.46^{\mathrm{ab}} \pm 0.23$ & $790.30^{\mathrm{cd}} \pm 1.54$ & $79.78^{\mathrm{abc}} \pm 0.13$ \\
\hline VB7 & $93.77^{\mathrm{bc}} \pm 0.74$ & $85.18^{\mathrm{a}} \pm 1.45$ & $159.97^{\mathrm{a}} \pm 0.24$ & $896.31^{\mathrm{a}} \pm 1.65$ & $75.63^{\mathrm{cd}} \pm 0.72$ \\
\hline VB8 & $86.94^{\mathrm{d}} \pm 1.03$ & $86.87^{\mathrm{a}} \pm 3.69$ & $154.61^{\mathrm{de}} \pm 0.30$ & $791.25^{\mathrm{cd}} \pm 7.35$ & $77.35^{\mathrm{cd}} \pm 1.08$ \\
\hline VB9 & $93.91^{\mathrm{bc}} \pm 0.16$ & $85.22^{\mathrm{a}} \pm 0.41$ & $151.26^{\mathrm{f}} \pm 1.25$ & $798.64^{\mathrm{c}} \pm 0.27$ & $80.03^{\mathrm{abc}} \pm 0.29$ \\
\hline
\end{tabular}

Values are means \pm SD. means with different superscripts in the same column are significantly different $(\mathrm{p}<0.05), \mathrm{VB} 1=$ poultry manure at $5.0 \times 10^{3} \mathrm{~kg} / \mathrm{ha} ; \mathrm{VB} 2=$ Poultry manure at $2.5 \times 10^{3} \mathrm{~kg} / \mathrm{ha}+\mathrm{NPK}$ 15:15:15 at $200 \mathrm{~kg} / \mathrm{ha} ; \mathrm{VB} 3=$ Agrolyser $2.7 \mathrm{~kg} / \mathrm{ha}+\mathrm{NPK}$ at $200 \mathrm{~kg} / \mathrm{ha} ; \mathrm{VB} 4=$ Poultry manure at $5.0 \mathrm{x}$ $10^{3} \mathrm{~kg} / \mathrm{ha}+\mathrm{NPK}$ at $200 \mathrm{~kg} / \mathrm{ha} ; \mathrm{VB} 5=\mathrm{NPK} 15: 15: 15$ at $400 \mathrm{~kg} / \mathrm{ha} ; \mathrm{VB} 6=$ Agrolyzer at $5.3 \mathrm{~kg} / \mathrm{ha} ; \mathrm{VB} 7=$ Poultry manure at $10.0 \times 10^{3} \mathrm{~kg} / \mathrm{ha} ; \mathrm{VB} 8=$ Poultry manure at $2.5 \times 10^{3} \mathrm{~kg} / \mathrm{ha}+\mathrm{NPK}$ at $200 \mathrm{~kg} / \mathrm{ha}+$ Agrolyser at $2.7 \mathrm{~kg} / \mathrm{ha}$; VB9 = Control

3.3.Vitamin Content of UMUSPO 3 IpomeabatatasVariety Cultivated under Different Soil Nutrient Management Treatments

Table 3 show vitamin composition of nine (9) potato (IpomeabatatasUMUSPO 3) samples grown on untreated soil and eight soils samples with different soil nutrient treatments.

Soil nutrient management did not significantly $(\mathrm{p}>0.05)$ improve vitamin $\mathrm{B}_{1}$ (Thiamine) and pro-vitamin A contents. Vitamin $B_{1}$ was $0.29 \mathrm{mg} / 100 \mathrm{~g}$ in both the control, VB9 and the treated samples, VB2 VB6 and there were no significant differences between these samples and values for other samples. However, values of thiamine content reported in this study are higher than 0.08 $\mathrm{mg} / 100 \mathrm{~g}$ reported by USDA (2001) National Database on sweet potato. Soil nutrient management, improved vitamin $\mathrm{B}_{3}$ (niacin) contents of the potatoes. Pro-vitamin A (Betacarotene) ranged from $28.52-29.53 \mathrm{mg} / 100 \mathrm{~g}$ in the potato samples. On the other hand, vitamin $\mathrm{B}_{3}$ content increased from $1.01 \mathrm{mg} / 100 \mathrm{~g}$ in potatoes from the control soil, VB9, to 1.42 $\mathrm{mg} / 100 \mathrm{~g}$ through $1.94 \mathrm{mg} / 100 \mathrm{~g}$ in potatoes from treated soils. Also, vitamin $\mathrm{B}_{2}$ (Riboflavin) was poor in all the potato samples harvested from soils with different nutrient treatment. It remained $0.09 \mathrm{mg} / 100 \mathrm{~g}$ in potatoes harvested from VB9 (the control), VB1 and VB2 but improved to $0.10 \mathrm{mg} / 100 \mathrm{~g}$ in potatoes harvested from VB8 (treated with Poultry manure at $2.5 \mathrm{x}$ $10^{3} \mathrm{~kg} / \mathrm{ha}+\mathrm{NPK}$ at $200 \mathrm{~kg} / \mathrm{ha}+$ Agrolyser at 2.7 $\mathrm{kg} / \mathrm{ha}$ ) and $0.11 \mathrm{mg} / 100 \mathrm{~g}$ in VB3 (soil, treated with Agrolyser $2.7 \mathrm{~kg} / \mathrm{ha}+\mathrm{NPK}$ at $200 \mathrm{~kg} / \mathrm{ha}$ ). Also, only nutrient treatment VB4 (Poultry manure at $5.0 \times 10^{3} \mathrm{~kg} / \mathrm{ha}+\mathrm{NPK}$ at $200 \mathrm{~kg} / \mathrm{ha}$ ) significantly $(\mathrm{p}<0.05)$ improved vitamin $\mathrm{C}$ (ascorbic acid) content of potatoes from 84.55 $\mathrm{mg} / 100 \mathrm{~g}$ in the control to $95.37 \mathrm{mg} / 100 \mathrm{~g}$. Other treatments either did not or decreased its content in the potatoes. UMUSPO 3 Ipomeabatatas is an excellent source of vitamin C. Vitamin $\mathrm{C}$ boosts immune systems, improves iron absorption, neutralizes blood toxins, and helps in maintaining epithelial cells and tissues. It promotes healthy gums, healing of wound and acts as natural antioxidant (Ojimelukweet al., 2005; Umesh, 2009). UMUSPO 3 Ipomeabatatas is also a rich source of vitamin $\mathrm{B}_{3}$, pro-vitamin $\mathrm{A}$ and vitamin $\mathrm{C}$ but poor in vitamins $B_{1}$ and $B_{2}$. Niacin (vitamin $B_{3}$ ) is necessary for glycolysis, tissue respiration and fat synthesis (Gropper et al., 2005). Betacarotene is essential for good vision, differentiation of epithelial issues, proper immune functions, healthy skin; hair and nails 
(Gropper et al., 2005; Ojimelukweet al., 2005; Umesh, 2009). The soil nutrient treatments did not improve the pro-vitamin A content of the samples.

Table 3. Effect of different nutrient management treatments on vitamin Content $\mathrm{mg} / 100 \mathrm{~g}$ of UMUSPO 3 Ipomeabatatasvariety

\begin{tabular}{|l|c|c|c|c|c|}
\hline Treatment & Vitamin $\mathbf{B}_{\mathbf{1}}$ & Vitamin $\mathbf{B}_{\mathbf{2}}$ & Vitamin $\mathbf{B}_{\mathbf{3}}$ & Pro-vitamin A & Vitamin C \\
\hline VB1 & $0.24^{\mathrm{a}} \pm 0.02$ & $0.09^{\mathrm{bc}} \pm 0.00$ & $1.94^{\mathrm{a}} \pm 0.00$ & $28.52^{\mathrm{c}} \pm 0.12$ & $73.79^{\mathrm{c}} \pm 0.18$ \\
\hline VB2 & $0.29^{\mathrm{a}} \pm 0.00$ & $0.09^{\mathrm{bc}} \pm 0.01$ & $1.42^{\mathrm{e}} \pm 0.02$ & $29.45^{\mathrm{ab}} \pm 0.26$ & $84.53^{\mathrm{b}} \pm 0.16$ \\
\hline VB3 & $0.28^{\mathrm{a}} \pm 0.01$ & $0.11^{\mathrm{a}} \pm 0.01$ & $1.47^{\mathrm{e}} \pm 0.01$ & $29.53^{\mathrm{a}} \pm 0.11$ & $63.34^{\mathrm{d}} \pm 0.09$ \\
\hline VB4 & $0.28^{\mathrm{a}} \pm 0.00$ & $0.06^{\mathrm{d}} \pm 0.00$ & $1.93^{\mathrm{a}} \pm 0.00$ & $29.33^{\mathrm{a}} \pm 0.16$ & $95.37^{\mathrm{a}} \pm 0.01$ \\
\hline VB5 & $0.28^{\mathrm{a}} \pm 0.00$ & $0.08^{\mathrm{cd}} \pm 0.00$ & $1.54^{\mathrm{d}} \pm 0.00$ & $29.35^{\mathrm{b}} \pm 0.13$ & $84.53^{\mathrm{h}} \pm 0.16$ \\
\hline VB6 & $0.29^{\mathrm{a}} \pm 0.00$ & $0.08^{\mathrm{c}} \pm 0.00$ & $1.63^{\mathrm{c}} \pm 0.00$ & $29.43^{\mathrm{a}} \pm 0.42$ & $58.33^{\mathrm{d}} \pm 7.16$ \\
\hline VB7 & $0.28^{\mathrm{a}} \pm 0.00$ & $0.07^{\mathrm{d}} \pm 0.00$ & $1.72^{\mathrm{b}} \pm 0.00$ & $29.44^{\mathrm{ab}} \pm 0.04$ & $84.52^{\mathrm{b}} \pm 0.17$ \\
\hline VB8 & $0.28^{\mathrm{a}} \pm 0.02$ & $0.10^{\mathrm{a}} \pm 0.00$ & $1.73^{\mathrm{b}} \pm 0.12$ & $29.73^{\mathrm{a}} \pm 0.4$ & $84.45^{\mathrm{b}} \pm 0.04$ \\
\hline VB9 & $0.29^{\mathrm{a}} \pm 0.05$ & $0.09^{\mathrm{bc}} \pm 0.00$ & $1.01^{\mathrm{f}} \pm 1.42$ & $29.53^{\mathrm{a}} \pm 0.12$ & $84.55^{\mathrm{b}} \pm 0.10$ \\
\hline
\end{tabular}

Values are means \pm SD. Means with different superscripts in the same column are significantly different $(\mathrm{p}<0.05) ; \mathrm{VB} 1=$ poultry manure at $5.0 \times 10^{3} \mathrm{~kg} / \mathrm{ha} ; \mathrm{VB} 2=$ Poultry manure at $2.5 \times 10^{3} \mathrm{~kg} / \mathrm{ha}+\mathrm{NPK}$ $15: 15: 15$ at $200 \mathrm{~kg} / \mathrm{ha} ; \mathrm{VB} 3=$ Agrolyser $2.7 \mathrm{~kg} / \mathrm{ha}+\mathrm{NPK}$ at $200 \mathrm{~kg} / \mathrm{ha} ; \mathrm{VB} 4=$ Poultry manure at $5.0 \mathrm{x}$ $10^{3} \mathrm{~kg} / \mathrm{ha}+\mathrm{NPK}$ at $200 \mathrm{~kg} / \mathrm{ha} ; \mathrm{VB} 5=\mathrm{NPK} 15: 15: 15$ at $400 \mathrm{~kg} / \mathrm{ha} ; \mathrm{VB} 6=$ Agrolyzer at $5.3 \mathrm{~kg} / \mathrm{ha} ; \mathrm{VB} 7$ $=$ Poultry manure at $10.0 \times 10^{3} \mathrm{~kg} / \mathrm{ha} ; \mathrm{VB} 8=$ Poultry manure at $2.5 \times 10^{3} \mathrm{~kg} / \mathrm{ha}+\mathrm{NPK}$ at $200 \mathrm{~kg} / \mathrm{ha}+$ Agrolyser at $2.7 \mathrm{~kg} / \mathrm{ha}$; VB9 $=$ Control

\subsection{Phytochemical composition of UMUSPO 3 Ipomeabatatasvariety cultivated under different soil nutrient management treatments}

Table 4 shows phytochemical (alkaloid, flavonoid, tannin and oxalate) contents oflpomeabatatas(variety: UMUSPO 3) cultivated under different soil nutrient management treatments. There was no significant differences $(p>0.05)$ in oxalate contents of UMUSPO 3 OFSP given different soil management treatments. The alkaloid content was highest for VB8 (Poultry manure at $2.5 \times 10^{3} \mathrm{~kg} / \mathrm{ha}+\mathrm{NPK}$ at $200 \mathrm{~kg} / \mathrm{ha}+$ Agrolyser at $2.7 \mathrm{~kg} / \mathrm{ha}$ ), but its tannin content was one of the lowest and only higher than VB1 (poultry manure at $5.0 \times 10^{3} \mathrm{~kg} / \mathrm{ha}$ ) Flavonoid, tannin and oxalate were very low in all the potato sample, and ranged from $0.81 \mathrm{mg} / 100 \mathrm{~g}$ to $0.04 \mathrm{mg} / 100 \mathrm{~g}$ in the potato samples. However, soil nutrient management significantly reduced oxalate content of potatoes from $1.22 \mathrm{mg} / 100 \mathrm{~g}$ in the control sample to as low as 0.60 in samples harvested from soil treated with Poultry manure at $2.5 \times 10^{3} \mathrm{~kg} / \mathrm{ha}+$ NPK $15: 15: 15$ at $200 \mathrm{~kg} / \mathrm{ha}$ (VB2). Flavonoids are secondary metabolites with health benefits and potentials for the prevention of carcinogenesis, cardiovascular diseases, diabetes, inflammation, arterioscleroses and aging. They act as free radical scavengers (Slimetad and Verhel, 2009; Ukomet al., 2014).Shekhar et al. (2015) as well as Anthoney and Owenga (2014) observed variations in the phytochemical contents of sweet potatoes. 
Table 4. Effect of different nutrient management treatments on phytochemicalcomposition $\mathrm{mg} / 100 \mathrm{~g}$ of UMUSPO 3 Ipomeabatatasvariety

\begin{tabular}{|l|c|c|c|c|}
\hline Treatment & Alkaloid & Flavonoid & Tannin & Oxalate \\
\hline VB1 & $0.63^{\mathrm{e}} \pm 0.04$ & $0.22^{\mathrm{c}} \pm 0.28$ & $0.24^{\mathrm{c}} \pm 0.01$ & $0.05^{\mathrm{a}} \pm 0.04$ \\
\hline VB2 & $0.60^{\mathrm{e}} \pm 0.01$ & $0.42^{\mathrm{b}} \pm 0.03$ & $0.43^{\mathrm{a}} \pm 0.03$ & $0.05 \mathrm{a} \pm 0.01$ \\
\hline VB3 & $0.84^{\mathrm{d}} \pm 0.05$ & $0.21^{\mathrm{c}} \pm 0.01$ & $0.43^{\mathrm{a}} \pm 0.01$ & $0.04^{\mathrm{a}} \pm 0.02$ \\
\hline VB4 & $1.10^{\mathrm{bc}} \pm 0.01$ & $0.44^{\mathrm{b}} \pm 0.06$ & $0.42^{\mathrm{a}} \pm 0.03$ & $0.05^{\mathrm{a}} \pm 0.01$ \\
\hline VB5 & $0.62^{\mathrm{e}} \pm 0.03$ & $0.24^{\mathrm{c}} \pm 0.57$ & $0.45^{\mathrm{a}} \pm 0.00$ & $0.04^{\mathrm{a}} \pm 0.03$ \\
\hline VB6 & $1.00^{\mathrm{c}} \pm 0.00$ & $0.81^{\mathrm{a}} \pm 0.01$ & $0.43^{\mathrm{a}} \pm 0.04$ & $0.04^{\mathrm{a}} \pm 0.03$ \\
\hline VB9 & $1.22^{\mathrm{b}} \pm 0.03$ & $0.40^{\mathrm{b}} \pm 0.00$ & $0.42^{\mathrm{a}} \pm 0.00$ & $0.04^{\mathrm{a}} \pm 0.00$ \\
\hline VB7 & $1.23^{\mathrm{b}} \pm 0.04$ & $0.43^{\mathrm{b}} \pm 0.00$ & $0.43^{\mathrm{a}} \pm 0.00$ & $0.06^{\mathrm{a}} \pm 0.02$ \\
\hline VB8 & $1.46^{\mathrm{a}} \pm 0.09$ & $0.43^{\mathrm{b}} \pm 0.04$ & $0.32^{\mathrm{b}} \pm 0.00$ & $0.08^{\mathrm{a}} \pm 0.04$ \\
\hline VB9 & $1.22^{\mathrm{b}} \pm 0.03$ & $0.40^{\mathrm{b}} \pm 0.00$ & $0.42^{\mathrm{a}} \pm 0.00$ & $0.04^{\mathrm{a}} \pm 0.03$ \\
\hline
\end{tabular}

Values are mean \pm SD. Mean values with different superscripts in the column are significantly different $(\mathrm{p}<0.05)$., VB1 = poultry manure at $5.0 \times 10^{3} \mathrm{~kg} / \mathrm{ha} ; \mathrm{VB} 2=$ Poultry manure at $2.5 \times 10^{3} \mathrm{~kg} / \mathrm{ha}+\mathrm{NPK}$ 15:15:15 at $200 \mathrm{~kg} / \mathrm{ha} ; \mathrm{VB} 3=$ Agrolyser $2.7 \mathrm{~kg} / \mathrm{ha}+\mathrm{NPK}$ at $200 \mathrm{~kg} / \mathrm{ha} ; \mathrm{VB} 4=$ Poultry manure at $5.0 \mathrm{x}$ $10^{3} \mathrm{~kg} / \mathrm{ha}+\mathrm{NPK}$ at $200 \mathrm{~kg} / \mathrm{ha} ; \mathrm{VB} 5=\mathrm{NPK} 15: 15: 15$ at $400 \mathrm{~kg} / \mathrm{ha} ; \mathrm{VB} 6=$ Agrolyzer at $5.3 \mathrm{~kg} / \mathrm{ha} ; \mathrm{VB} 7$ $=$ Poultry manure at $10.0 \times 10^{3} \mathrm{~kg} / \mathrm{ha} ; \mathrm{VB} 8=$ Poultry manure at $2.5 \times 10^{3} \mathrm{~kg} / \mathrm{ha}+\mathrm{NPK}$ at $200 \mathrm{~kg} / \mathrm{ha}+$ Agrolyser at $2.7 \mathrm{~kg} / \mathrm{ha} ; \mathrm{VB} 9=$ Control

\subsection{Effect of cooking methods on beta- carotene $(\mu \mathrm{g} / \mathrm{g})$ retention in UMUSPO 3 Ipomeabatatasvariety cultivated under different soil nutrient management treatments}

Table 5 shows the effects of cooking methods (oven-drying, roasting and boiling) on total carotenoid retention of Ipomeabatatas (UMUSPO 3). Oven-drying, roasting and boiling significantly $(\mathrm{p}<0.05)$ affected total carotenoid retention. Carotenoid loss increased with increasing cooking time. Oven-drying for $24 \mathrm{~h}$ reduced carotenoid content to $76.4 \%$, and for $48 \mathrm{~h}$ reduced the content to $36.9 \%$. Roasting for $10 \mathrm{~min}$ reduced total carotenoid content to $50.6 \%$, and for $30 \mathrm{~min}$ to $20 \%$ retention. On the other hand, boiling for $10 \mathrm{~min}$ reduced total carotenoid content to $56.4 \%$ while boiling for 30 min reduced total carotenoid content to $17.1 \%$. The longer time used in oven-drying was as a result of the low temperature regiment of $\leq 70^{\circ} \mathrm{C}$ generally employed in drying agricultural products to retain its functional properties. Effects of various traditional processing methods on carotenoids content of sweet potato have also been reported by Ukom and Ojimelukwe (2016);Bengtsonet al. (2008), among others. The difference in carotenoid retention in boiled sweet potato $(85-90 \%)$ (Vimalaet al, 2011) and highest values obtained in this work 56.4\% (UMUSPO 3) may be attributed to differences in cooking conditions, time and temperature (Timalsina et al., 2019). Roasting has been considered a good carotenoid retention method because roasting reduces moisture and concentrates the carotenoid per weight of the food (Ukomet al., 2011).Predrying, frying temperature and frying time affect the colour, crispiness moisture content and hardness of sweet potatoes (Tamalsina et al., 2019). 
Table 5. Effect of cooking methods on total carotenoid $(\mu \mathrm{g} / \mathrm{g})$ retention of UMUSPO 3 Ipomeabatatasvariety

\begin{tabular}{|l|c|c|c|}
\hline Processing Method & Cooking Time & $\begin{array}{c}\text { Carotenoid } \\
\text { Retention }\end{array}$ & $\begin{array}{c}\text { \%Total Carotenoid } \\
\text { retention }\end{array}$ \\
\hline Oven-drying & $0 \mathrm{~h}$ & $41.70^{\mathrm{a}} \pm 1.50$ & \\
\cline { 2 - 4 } & $24 \mathrm{~h}$ & $31.69^{\mathrm{b}} \pm 0.00$ & $76.4 \%$ \\
\cline { 2 - 4 } & $36 \mathrm{~h}$ & $27.48^{\mathrm{c}} \pm 0.00$ & $65.9 \%$ \\
\cline { 2 - 4 } & $48 \mathrm{~h}$ & $15.14^{\mathrm{d}} \pm 0.00$ & $36.3 \%$ \\
\hline \multirow{4}{*}{ Roasting } & $0 \mathrm{~min}$ & $41.70^{\mathrm{a}} \pm 1.50$ & $50.6 \%$ \\
\cline { 2 - 4 } & $10 \mathrm{~min}$ & $21.10^{\mathrm{b}} \pm 0.14$ & $29.2 \%$ \\
\cline { 2 - 4 } & $20 \mathrm{~min}$ & $12.20^{\mathrm{c}} \pm 0.00$ & $20.9 \%$ \\
\hline \multirow{3}{*}{ Boiling } & $30 \mathrm{~min}$ & $8.70^{\mathrm{d}} \pm 0.00$ & \\
\cline { 2 - 4 } & $0 \mathrm{~min}$ & $41.70^{\mathrm{a}} \pm 1.50$ & $56.4 \%$ \\
\cline { 2 - 4 } & $10 \mathrm{~min}$ & $23.50^{\mathrm{b}} \pm 0.57$ & $26.4 \%$ \\
\cline { 2 - 4 } & $20 \mathrm{~min}$ & $11.00^{\mathrm{c}} \pm 0.00$ & $17.1 \%$ \\
\hline
\end{tabular}

Values are means \pm SD. Means with different superscripts in the same column are significantly different $(\mathrm{p}<0.05)$.

The average loss of carotenoid was more in boiling than in roasting but least in oven-drying (see Figure 2). The figure indicates that ovendrying is a superior method of processing for carotenoid retention when compared with moist heat treatment and roasting.During heat treatment, there could be enzymatic or non- enzymatic oxidation as well as isomerization of cis to trans isomers of $\beta$-carotene, which alters their biological activity and denatures the food.There is the need to adapt the processing methods that will reduce $\beta$-carotene degradation (Rodriguez-Amaya, 1999 and Vimalaet al., 2011).

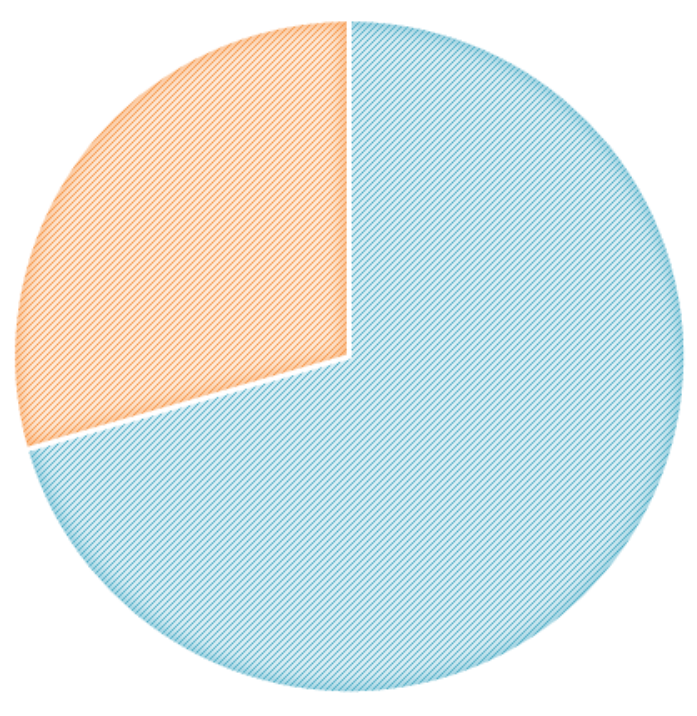

aven-drying (0-48h)

- Roasting 0-30 min

Boiling (0-30 min)

Figure 2. Average carotenoid retention after processing. 


\section{Conclusions}

Use of NPK fertilizer improves the protein content, while the use of poultry manure improves the ash content off orange-fleshed sweet potatoes. Application of poultry manure improves the niacin content of the potatoes. Vitamin B1 and pro-vitamin A contents are not improved by soil nutrient management treatments. Carotenoid retention during processing is highly dependent on the processing methods as carotenoids undergo some qualitative and quantitative changes during processing.

\section{REFERENCES}

Abidin, P.E.(2004). Sweet potato breeding for north eastern Uganda: Farmer varieties, farmer participatory selection and stability of performance. $\mathrm{PhD}$ thesis, Wageningen University. The Netherland, pp. 152.

Anthoney, S. T., Omwenga, J. (2014) Analysis of phytochemical composition of white and purple sweet potato (Ipomoea batatas [L] Lam) root. Indian J Adv Plant Res 2014; 1, 19-22.

AOAC (2000). Official methods of analysis, $16^{\text {th }}$ edition. Association of Official Analytical Chemists, Washington DC.

A, Bengtson, A., Brackmann, C., Enejder, A. (2010). Effects of Thermal Processing on the in Vitro Bioaccessibility and Microstructure of Carotene in OrangeFleshed Sweet Potato. Journal of Agricultural Food Chemistry. 34(4):23-45.

Chukwu, O., Orhhevba, B.A., and Mahmood, B.A. (2010). Influence of hydrothermal treatments on proximate compositions of fermented locus bean. Journal of Food Technology. 8(3): 99-101.

Esan, T.A., Sobukola, O.P., Sanni, L.O., Bakare, H.A., Munoz, L. (2015) Process optimization by response surface methodology and quality attributes of vacuum fried yellow fleshed sweet potato (Ipomoea batatas L.) chips, Food Bioproduct Processing, 95, 27-37

FAO/WHO (1991). Energy and Protein requirements: Report of a Joint $\mathrm{FAO} / \mathrm{WHO} / \mathrm{UNU}$
Gropper, S. S, Smith, J. C, Groff, J. L. (2005). Advance Nutrition and Human Metabolism. Thompson Wadsworth, Australia, Canada, UK, US.

Harborne, J. B. (1973). Phytochemical methods; A guide to modern techniques of plant analysis, Chapman and Hall Ltd, London

Kirk, R.S, Sawyerm R. (1991) Pearson's composition and analysis of foods. 9th edition (student edition), England, Addison, Wiley, Longman Ltd

Mitra, S. (2012) Nutritional Status of OrangeFleshed Sweet Potatoes in Alleviating Vitamin A Malnutrition through a FoodBased Approach. Journal of Nutrition \& Food Sciences, 2012 2-8. DOI: 10.4172/2155-9600.1000160

Nedunchezhiyan, M., Byju, G., Naskar, S.K. (2007) Sweet potato (Ipomoea batatas L.) as an intercrop in a coconut plantation: Growth, yield and quality. Journal of Root Crops 33 (1), 26-29

Nedunchezhiyan, M.,Byju, G.,Jata, S.K (2012) Sweet potato agronomy. Fruit, Vegetable, Cereal Science and Biotechnology 6 (Special Issue 1), 1-10 (C2012 Global Science Book

Niseteo, T., Komes, D., Belsack-Cvitanovic, A., Horžić, D., Budeč, M. (2012) Bioactive composition and antioxidant potential of different commonly consumed coffee brews affected by their preparation technique and milk addition. Food Chemistry 134(4), 1870-7

Ojimelukwe, P.C., Asumugha, V.U., Omeire, G.C. (2005) Fundamentals of Food Science and Nutrition. Bel Books, Nsukka, Nigeria

Oke, O. L. (1966) Chemical studies on the more commonly used vegetables in Nigeria. Journal of West African Science Association $11,42-48$.

Okwu, D.E. (2004) Phytochemicals and vitamin content of indigenous spices of Southeastern Nigeria. Journal of Sustainable Agriculture and Environment. 6(1), 30- 37.

Okwu, D.E, Josiah, C. (2006). Evaluation of the Chemical composition of two Nigeria Medicinal plants. African journal of Biotechnology. 5(4), 357-361. 
Okwu, D.E. ,Ndu, C.U. (2006) "Evaluation of phyto-nutrients, minerals and vitamin content of some varieties of yam (Dioscoprea spp.)," International Journal of Molecular Medicine and Advance Sciences, vol. 2, pp. 199-203, 2006.

Onuh, J.O., Akpapunam, M.A, Iwe, M.O. (2004) Comparative Studies of the Physicochemical Properties of Two Local Varieties of Sweet Potato Flours. DOI: 10.4314/nifoj.v22i1.33579

Shekhar, S., Mishra, D., Buragohain, A.K., Chakraborty S,Chakraborty N (2015) Comparative analysis of phytochemicals and nutrient availability in two contrasting cultivars of sweet potato (Ipomoea batatas L.). Food Chemistry 2015; 173, 957-965.

Slimetad, R., Verhel, M. (2009) Review of flavonoids and other phenolics from fruits of different tomato (LycopersiconesculentumMill) cultivars, Journal of Science of Food and Agriculture, 89, 2009, 1255-1270

Timalsina, P., Prajapati, R., Bhaktaraj, S., Shrestha, R., Shrestha, S. P., Mitra, P. (2019). Sweet Potato Chips Development andOptimization of Chips Processing Variables. Open Agriculture. 2019; 4, $118-$ 128. https://doi.org/10.1515/opag-20190011

Ukom, A. N., Ojimelukwe, P.C., Okpara, D.A.(2009). "Nutrient composition of selected sweet potato () varieties as influenced by different levels of fertilizer application," Pakistan Journal of Nutrition, vol. 8, pp. 1791-1795, 2009.

Ukom, A.N., Ojimelukwe, P.C., Ezeama, C.F., Ortiz, D.O., Aragon, I.I. (2014) Proximate composition and carotenoid profile of yams (Dioscorea spp.) and cocoyam (Xanthosomamaffa(Scoth)) root tubers from Nigeria. American Journal of Food and Nutrition, 4(1), 1-10.

Ukom, A.N.,Ojimelukwe, P.C. (2016) Changes in $\beta$-carotene Content of Thermally Processed Sweet Potato (Ipomoea batatas) Cultivar. Journal of Applied Life Sciences International 5(1), 1-7, 2016
Umesh, R. (2009) Health Benefits of Sweet Potato. www.nutrition-and-you.com.

USDA (United States Department of Agriculture, Agricultural Research Science) (2001).

Vimala, B., Nambisan, B. and Hriprakash, B. (2011). Retention of Carotenoids in Orange-Fleshed Sweet Potato during Processing. Journal of Food Science and Technology, 48 , 520-524.

Yang, J., Gradi, R.L. (2008) Effects of steaming and dehydration on anthocyanins, antioxidant activity, total phenols, and colour characteristics of purple flashed sweet potatoes (Ipomea batatas). American Journal of Food Technology 3, 224-234. 